\title{
Effects of Employee Career Management on Organisational Performance: A Study of Selected Banks in Umuahia, Abia State
}

\begin{abstract}
Assoc. Prof. Dialoke, Ikechukwu
Department of Industrial Relations \& Personnel Management, College of Management Sciences, Michael Okpara University of Agriculture, Umudike
\end{abstract}

Tel: 234-703-902-3340Ｅ-mail: drikechukwudialoke@yahoo.com

Chiavoghi, Nnaemeka

Department of Industrial Relations \& Personnel Management, College of Management Sciences, Michael Okpara University of Agriculture, Umudike

Tel: 234-806-673-0288Ｅ-mail: nchiavoghi@yahoo.com

\begin{abstract}
Ukonu, Ifeanyichukwu Ojeka
Department of Industrial Relations \& Personnel Management, College of Management Sciences, Michael Okpara University of Agriculture, Umudike

Tel: 234-815-656-2711Ｅ-mail: bobify@yahoo.com
\end{abstract}

Received: Oct. 31, 2016 Accepted: Nov. 6, 2016 Published: December 12, 2016

doi:10.5296/bms.v7i2.10237 URL: http://dx.doi.org/10.5296/bms.v7i2.10237

\begin{abstract}
This study examines the effects of employee career management on organisational performance of selected banks in Umuahia, Abia State, Nigeria. Quasi-experimental research design was employed. Target population for the study consists of licensed commercial banks in Umuahia but accessible population consists of 10 banks. Simple random sampling was used. Sample frames of 213 bank workers were surveyed through questionnaire
\end{abstract}




\section{Macrothink}

administration. Sample size is 134 using Taro Yamane formular. After data cleaning, a total of 91 copies were found useful for data analysis. Spearman's Rank Order Correlation Coefficient was used for data analysis with the aid of Statistical Package for Social Sciences (SPSS). Findings of the study show that employee career management is significantly associated with organisational performance. The study concluded that employee career management promotes organisational performance of banks. Drawing from the conclusion, the study recommended that financial institutions should encourage their employees by developing their career through training, seminars, conferences and educational advancement to update their knowledge in other to be competitive in the banking industry.

Keywords: Career, Career management, Career counseling, Career development, Organisational performance, Effectiveness, Efficiency 


\section{Introduction}

The ultimate goal of every organization is to make profit and equally provide services to the people. This objective may not be feasible if the career path of the employee that carryout the work is not properly incorporated in the organisation's road of success. Employee career management has been a challenging issue among human resource manager's as well as scholars due to globalization. However, as an organisation seeks to grow in terms of size, profit and technology; its employees should also be included in the growth circle. This is because employees are the machinery that drives growth in every enterprise. Taking cognizance of this fact; it therefore implies that human resource department is saddled with the responsibility of counseling the employees in line with their aspirations and visions for the future.

However, in this era of technological competitiveness, human resource personnel are designing best approaches for employee career guidance that will create opportunity for advancement. Supporting this argument, Moses (1995) contended "in today's fast-changing workplace, people need the skills and competencies to ensure future employability, and to manage new work and life realities. Organizations need flexible people, who can effectively manage change and adapt to new organizational directions. The key to achieving these goals, for both the individual and the organization, is career self-management". From the foregoing submission, it therefore implies that employees can effectively manage their career to any length they want. The current trend in career management has been how to increase the skills of employees to meet the turbulences facing the organization.

One major aim of any career management in the organization is to guide employee's career and how he/she can achieve enterprise effectiveness (Greenhaus, Callanan and Godshalk, 2010). Nevertheless, in the $21^{\text {st }}$ century, the basic aim of career management was shifted on staff and how they will achieve their own objectives in congruence with that of the organization (Okwiet, 2014). In line with Okwiet's submission, Hameed and Waheed (2011) advocated that "when organizations are engaged in employee development, the employees on the one hand tend to put more effort on their jobs by using their skills to improve workplace objectives". Career management officers in public and private organisations should create a conducive atmosphere for employee's progress in their career. Subscribing to this assertion, Osibanjo, Oyewunmi and Ojo (2014) contended that organization's must provide enabling environment for employees growth opportunities, which tend to motivate, promote, recognize, reward, and retain valuable employees. Employees should be given the opportunity for career advancement through career management in the organization to enable them plan for their future and that of the enterprise to avoid turnover which will affect production or service delivery. That is why Sean (2013) accentuated that "if peoples' desire to make advancement in their own career is not fulfilled, they will begin looking for work elsewhere".

What then is career management? Career management refers to the programs or activities provided by organizations to support their employees' career success (Kong et al., 2010). Hall (1986) viewed career management "to be an organizational process that involves 
preparing, implementing, and monitoring career plans undertaken by an individual alone or within the organization's career systems". On the one hand, Cascio (2007) contended that performance is the degree to achieve firm's mission which will enhance employee work. Drawing from the above, the point of departure of this study is to empirically ascertain how employee career management can enhance organisational performance in selected banks in Umuahia, Abia State, Nigeria.

\section{Literature Review}

\subsection{The Concept of Employee Career Management}

Career management has been an issue in human resource management. This literature will view various scholars' opinion on the subject matter. What is career? Dessler (2013) defined career as the occupational positions a person has had over many years. Greenhaus, Callanan and Godshalk (2010) opined that career management as the process by which individuals collect information about values, interests, skill strengths and weaknesses, identify a career goal, and engage in career strategies that increase the probability that career goals to be achieved. Noe (1996) in his study defined career management as: "career exploration, development of career goals, and career strategy implementation". Career management (or organizational career management) has been described as a series of formal and less formal activities designed and managed by the organization to influence the career development of one or more employees (Arnold, 1996). Dessler (2013) viewed career management as the process for enabling employees to better understand and develop their career skills and interests, and to use these skills and interests more effectively. Armstrong (2006) in his submission argued that career management is concerned with providing opportunities for people to progress and develop their careers and ensuring that the organization has the flow of talent it needs. What is the essence of career management? Okwiet (2014) submitted that "the reason for career management is primarily based on employee and how he/she can achieve their personal goals other than the objectives of the organization.

However, Grabara (2006) in Okwiet (2014) argued that for career management to yield positive result, it must meet the following conditions:

I. Career management depends on the deep knowledge of the employee as well as the picture of the work environment. This is because most of the employees don't know anything concerning their personality.

II. Secondly, career management also depends on the development of definite objectives, that will fits to employee's personality

III. Thirdly, career management solely rests on the development and implementation of proper approaches to career.

IV. Finally, career management depends on continuous feedback process. 
Nevertheless, few empirical studies on career management were recorded in the literature. Kraimer, et al. (2003) examined employee performance and turnover intentions from a career perspective. They found that promotional opportunities and informal organizational career management activities, namely informal career discussions with a manager and participation in challenging job. Khuida and Siti (2004) examined the relationship between organizational career management and individual performance. The finding of their study shows that there was significant and positive relationship between organization career management and the individual performance. Van Dam (2004) examined the antecedents and consequences of employability orientation. The finding of their study shows that people who experience more organizational support have a higher employability orientation. Rebeccah, (2011) examined the factors affecting career management among non-academic staff in public universities in Kenya: A case study of Jomo Kenyatta university of agriculture and technology. The study established that career planning, training and development and institutional framework had a positive effect on career management in JKUAT. lyria, Namusonge and Karanja (2014) examined the effect of career management to the organizational performance in companies listed in Nairobi Security Exchange in Kenya. The findings of their study indicated career management as a component of talent management had a positive and significant influence on the organizational performance. Ngirande and Musara (2014) studied career management practices: impact of work design on employee retention. The study found a strong correlations between job enrichment, job design and job enlargement. Sidiropoulou-Dimakakou et al. (2015) highlighted a grid of career management skills which can help university students respond effectively to the complexity of labor market and career development, namely, career adaptability, perceived career self-efficacy beliefs and career resilience. The results of their study demonstrated relatively high scores in all skills, strong positive relationships among them as well as significant differences at scores as to students work status. Wong and Quek (2015) examined the factors that affect undergraduates' perception towards career management in Malaysia's higher education institutions. The findings of their study suggest that individual-related factors (self-efficacy and outcome expectations) and social-related factor (peer influences) have positive relationship with individual career management. Khulida and Fee-Yean (2015) carried out a study on enhancing career commitment: The influence of human resource management practices. The regression results of the study indicated that compensation, and training and development were significant predictors to enhance career commitment.

Finally, Mabwe (2015) explored the influence of best career management practices on both individual and organizational performance. The finding of Mabwe's study revealed that organizations should place more high value on career management practices as it has proven to have positive effect on organisational performance.

The above scholars has made tremendous efforts in establishing empirical foundations on career management therefore have contributed immensely to knowledge. However, most of them did not carry out their studies in the banking sector especially in the Nigerian context. It was also very clear that none of them examined the effect of employee career management on 
organisational performance. This study is to fill the lacuna that exists in the career management literature.

\subsection{Measures of Employee Career Management}

There are several factors that can used to determine how effective employee career management can be handled. Maina (2011) conceptualized career planning, training and development, institutional framework, and work-life balance as the factors that can influence career management. Organizational career management practices includes; performance appraisal as a basis of career planning, career centres, career counselling by the human resource department, formal mentoring, career workshops, retirement preparation programmes, succession planning, formal education as a part of career development and lateral moves to create cross functional experience (Agarwala, 2007). This study however is limited to career counseling and career development as explained below.

\subsubsection{Career Counseling}

This refers to a sequence of activities aimed at assisting an individual to make informed decisions about work or about work related problems (Ombay, Otuya and Shiamwama, 2013). Gichinga (2011) viewed counselling as a relationship in which one person helps another to understand and solve their problems-the ultimate goal is a helping relationship. Career counselling can also be seen as a personalised process that helps a person understand themselves, explore career options, and clarify and obtain desired career goals. It contributes intuitive and cognitive technique (Nthangi, 2007). Ombay, Otuya and Shiamwama (2013) argued that career counselling is a two way process in which the counsellor and the counselee both contribute to make career counselling efficient and effective. In this study, career counseling simply means a process whereby a counselor (an expert in career management, senior manager, human resource manager or someone who has worked over a period of time with the same industry) helps the counselee (employee) to achieve both his goal and that of the organization.

\subsubsection{Career Development}

Career development describes the lifelong process of managing life, learning and work (Kagwiria, Namusonge and Karanja, 2014). It involves individuals' planning and making decisions about education, training and career choices as well as developing the right skills and knowledge to do this (Farrell and Grant (2005). Agba, Festus and Ushie (2010) argued that career development involves concerted efforts directed towards assessing a workers' potentials identifying likely career paths for that employee and designing and implementing "various forms of training and experience to prepare that person for more advanced job". Aplin and Gerster (1978) submitted that the essence of career development is to match an employee's career aspirations with opportunities and challenges available within the organization. In this study, career development means those activities that will enable employees to update their knowledge in other to be competitive e.g. training, seminars, conferences and educational advancement. 


\subsection{The Concept of Organisational Performance}

Several authors have written extensively on organisational performance (Mkoji and Sikalieh, 2012; Sofijanova and Zabijakin-Chatleska, 2013; Zakari, Poku and Owusu-Ansah, 2013; Azara, Syed and Muhammad, 2013; Lambe, 2014; and; Peace and Mohammed, 2014). But more clarifications need to be made between organisational performance and performance. Performance is a set of financial and nonfinancial indicators which offer information on the degree of achievement of objectives and results (Lebans and Euske 2006). Performance is dynamic, requiring judgment and interpretation (Lebans and Euske, 2006). Daft (2000) organisational performance is defined as an organisation's ability to attain its goals by using resources in an efficient and effective manner. Organizational performance refers to the ability of an enterprise to achieve such objectives as high profit, quality product, large market share, good financial results, and survival at predetermined time using relevant strategy for action (Koontz and Donnell, 1993). Organisational performance is a reflection of productivity of members of an enterprise measured in terms of revenue, profit, growth, development and expansion of the organization (Kehinde, Jegede, and Akinlabi, 2012). Researchers have empirically examined the influence of organisational factors on organisational performance with findings. Mkoji and Sikalieh (2012) examined how personality dimensions impact on corporate organizational performance. The findings of their study showed that the conscientiousness personality trait is the most predictive of job performance at followed by openness to experience, agreeableness, extraversion and emotional stability.

Sofijanova and Zabijakin-Chatleska (2013) explores the relationship between employee involvement in decision making and problem solving and perceived organizational performance. Their study found that employee participation and empowerment programs, and the use of self-managing teams have a direct and statistically significant correlation to the managerial perception of the organizational performance. Zakari, Poku and Owusu-Ansah (2013) examined the relationship between organisational culture and performance in the banking industry in Ghana. They finding of their study shows that, there was a positive relationship between organisational culture and performance in the banking industry in Ghana. Adebayo, Ayeni and Oyewole (2013) examined the relationship between three corporate governance mechanisms (Board independence, board size, and chief executive duality) and two organization performance measures (earnings per share and return to equity) of Nigerian listed organizations. The result of their study showed that there is positive significant relationship between board independence and organizational performance while board size and chief executive duality have negative significant relationship with organizational performance. Azara, Syed and Muhammad (2013) examined employees training and organizational performance: Mediation by employees performance. Overall results of their study revealed significant and positive association between training and organization performance. Nada and Ibrahim (2014) examined the impact of core competences on organizational performance in Iraq banking sector. The result of their study shows that core competences is significantly associated with organizational performance. Lambe (2014) examined the effect of corporate governance on organizational performance in 
the Nigerian Banking Industry. The study concluded that, corporate governance is necessary to achieve the proper functioning of banks and that corporate governance can prevent bank distress only if it is well implemented. Peace and Mohammed (2014) examined the effect of employee commitment on organizational performance in Nigeria. The finding of their study indicates that employee commitment is fairly associated with organizational performance.

\subsubsection{Organisational Performance Indicators (Measures)}

Researchers across the globe have written so much on the criteria's or approaches in which organisational performance can be measured. However, Kaplan and Norton (2003) elucidated that organisational performance can be measured using "The Balanced Scorecard Perspectives". The Balanced Scorecard is a performance management tool for measuring whether small-scale operational activities of a company are aligned with its large-scale objectives in terms of vision and strategy (Carmeli and Tishler, 2004).The Balanced Scorecard include: financial perspectives, the customer perspectives, the internal perspective and, the innovation and learning perspectives. Another scholar, Katou (2008) contended that; the constituents of organisational performance construct are effectiveness, efficiency, development, satisfaction, innovation and high quality product.

This study will examine the effectiveness of banks in Umuahia, and efficiency towards achieving organisational performance using Chenhall and Langfield-Smith (2007) multiple perspectives of performance measures scale. The following indicators have been defined by different scholars (Katou; 2008; Dwight, 2012) as observed below.

Efficiency: This means the achievement of organisational objectives by using minimal resources (Katou, 2008). In this context, efficiency refers to a situation whereby a bank uses the available resources at its disposal to achieve organisational set goals.

Effectiveness: This refers to how organisation meets its objectives (Katou, 2008). Another scholar Dwight (2012) viewed effectiveness this way. "Effectiveness is a qualitative characteristic that indicates the extent to which targeted problems are addressed and the degree to which preset goals and objectives are achieved". In this study, effectiveness means the ability of banks to meet their set goals at the right time as stated in the bank's philosophy.

The study formulated four null hypotheses to test the relationship between employee career management dimensions and measures of organisatonal performance.

$\mathbf{H O}_{1}$ : There is no significant relationship between career counseling and efficiency.

$\mathbf{H O}_{2}$ : There is no significant relationship between career counseling and effectiveness.

$\mathbf{H O}_{3}$ : There is no significant relationship between career development and efficiency.

HO$_{4}$ : There is no significant relationship between career development and effectiveness.

\section{Methodology}

Research Design This study adopted a quasi-experimental research design. 


\section{Macrothink}

Population: The target population for the study consists of licensed commercial banks in Umuahia but accessible population consists of 10 banks.

Sample frame: 213 workers

Sampling Technique: Simple random sampling technique.

Sample Size: 134 using Taro Yamane sample size determination formular. Kumar (2005) formular was used for sample size proportion determination.

Instruments: 134 questionnaire were administered to ten banks in Umuahia. After collecting the questionnaire, a total of 91 copies were found useful for data analysis. Validity: Instrument validity was achieved through content and face validity.

Reliability: Reliability of the instrument was ascertained using Cronbach Alpha test. Measurement of variables: The antecedents of employee career management (career counseling and career development) were measured with 14 items on a 5-point Likert scale ranging from 5=Strongly Agree, 4=Agree, 3=Strongly Disagree, 2= Disagree, 1=Undecided. Measures of organisational performance were also measured on a 5-point Likert scale ranging from 5=Strongly Agree, 4=Agree, 3=Strongly Disagree, 2= Disagree, 1=Undecided with 14 items.

Statistical tool: Spearman's Rank Order Correlation Coefficient to ascertain the effect of employee career management on organisational performance.

\section{Data Analysis and Results}

Spearman's Rank Order Correlation Coefficient was used to analysed the data with the aid of Statistical Package for Social Sciences (SPSS). According to Kothari (2013) Spearman Rank Order Correlation Coefficient is a measure of association that is based on the ranks of the observations and not on the numerical values of the data. The results of the tested null hypotheses were presented below.

$\mathbf{H O}_{1}$ : There is no significant relationship between career counselling and efficiency in selected banks in Umuahia.

Table 1. Relationship between career counselling and efficiency 


\begin{tabular}{|c|c|c|c|c|}
\hline & & & counselling & Efficiency \\
\hline \multirow[t]{6}{*}{$\begin{array}{l}\text { Spearma } \\
\text { n's rho }\end{array}$} & counselling & $\begin{array}{l}\text { Correlation } \\
\text { Coefficient }\end{array}$ & 1.000 & $.724^{* *}$ \\
\hline & & Sig. (2-tailed) & . & .000 \\
\hline & & $\mathrm{N}$ & 91 & 91 \\
\hline & Efficiency & $\begin{array}{l}\text { Correlation } \\
\text { Coefficient }\end{array}$ & $.724^{* *}$ & 1.000 \\
\hline & & Sig. (2-tailed) & .000 & . \\
\hline & & $\mathrm{N}$ & 91 & 91 \\
\hline
\end{tabular}

As shown in the table above, results indicated that career counselling has a positive significant effect on efficiency ( $r h o=.724 * *, p<0.05=0.00$ ) which did not support the null hypothesis. The study therefore rejects the null hypothesis and accepts the alternate hypothesis which states that there is a significant relationship between career counselling and efficiency that increases organisational performance in selected banks in Umuahia.

$\mathbf{H O}_{2}$ : There is no significant relationship between career counselling and effectiveness in selected banks in Umuahia.

Table 2. Relationship between counselling and effectiveness

\begin{tabular}{|c|c|c|c|c|}
\hline & & & Counselling & Effectiveness \\
\hline \multirow[t]{6}{*}{$\begin{array}{l}\text { Spearma } \\
\text { n's rho }\end{array}$} & Counseling & $\begin{array}{l}\text { Correlation } \\
\text { Coefficient }\end{array}$ & 1.000 & $.800^{* *}$ \\
\hline & & Sig. (2-tailed) & . & .000 \\
\hline & & $\mathrm{N}$ & 91 & 91 \\
\hline & Effectiveness & $\begin{array}{l}\text { Correlation } \\
\text { Coefficient }\end{array}$ & $.800^{* *}$ & 1.000 \\
\hline & & Sig. (2-tailed) & .000 & . \\
\hline & & $\mathrm{N}$ & 91 & 91 \\
\hline
\end{tabular}


As shown in the table above, results indicated that career counselling has a positive significant effect on effectiveness $\left(\mathrm{rho}=.800^{* *}, \mathrm{p}<0.05=0.00\right.$ ) which did not support the null hypothesis. The study therefore rejects the null hypothesis and accepts the alternate hypothesis which states that there is a significant relationship between career cunselling and effectiveness that increases organisational performance in selected banks in Umuahia.

HO$_{3}$ : There is no significant relationship between career development and efficiency in selected banks in Umuahia.

Table 3. Relationship between career development and efficiency

\begin{tabular}{|c|c|c|c|c|}
\hline & & & $\begin{array}{l}\text { Career } \\
\text { devt. }\end{array}$ & Efficiency \\
\hline \multirow[t]{6}{*}{$\begin{array}{l}\text { Spearma } \\
\text { n's rho }\end{array}$} & \multirow[t]{3}{*}{$\begin{array}{c}\text { Career } \\
\text { development }\end{array}$} & $\begin{array}{l}\text { Correlation } \\
\text { Coefficient }\end{array}$ & 1.000 & $.711^{* *}$ \\
\hline & & Sig. (2-tailed) & . & .000 \\
\hline & & $\mathrm{N}$ & 91 & 91 \\
\hline & \multirow[t]{3}{*}{ Efficiency } & $\begin{array}{l}\text { Correlation } \\
\text { Coefficient }\end{array}$ & $.711^{* *}$ & 1.000 \\
\hline & & Sig. (2-tailed) & .000 & . \\
\hline & & $\mathrm{N}$ & 91 & 91 \\
\hline
\end{tabular}

As shown in the table above, results indicated that career development has a positive significant effect on efficiency ( $r h o=.711^{* *}, \mathrm{p}<0.05=0.00$ ) which did not support the null hypothesis. The study therefore rejects the null hypothesis and accepts the alternate hypothesis which states that there is a significant relationship between career development and efficiency that increases organisational performance in selected banks in Umuahia.

HO$_{4}$ : There is no significant relationship between career development and effectiveness in selected banks in Umuahia.

Table 4. Relationship between career development and effectiveness 
Career

Effectiveness

development

\begin{tabular}{|c|c|c|c|c|}
\hline \multirow[t]{6}{*}{$\begin{array}{l}\text { Spearma } \\
\text { n's rho }\end{array}$} & $\begin{array}{l}\text { Career } \\
\text { development }\end{array}$ & $\begin{array}{l}\text { Correlation } \\
\text { Coefficient }\end{array}$ & 1.000 & $.832^{* *}$ \\
\hline & & Sig. (2-tailed) & . & .000 \\
\hline & & $\mathrm{N}$ & 91 & 91 \\
\hline & Effectiveness & $\begin{array}{l}\text { Correlation } \\
\text { Coefficient }\end{array}$ & $.832^{* *}$ & 1.000 \\
\hline & & Sig. (2-tailed) & .000 & . \\
\hline & & $\mathrm{N}$ & 91 & 91 \\
\hline
\end{tabular}

As shown in the table above, results indicated that career development has a positive significant effect on effectiveness ( rho $=.832 * *, \mathrm{p}<0.05=0.00$ ) which did not support the null hypothesis. The study therefore rejects the null hypothesis and accepts the alternate hypothesis which states that there is a significant relationship between career development and effectiveness that increases organisational performance in selected banks in Umuahia.

\section{Discussion of Findings}

Based on the SPSS results above, the following findings were drawn. In hypothesis one, the study found that there is a significant relationship between career counseling and efficiency in selected banks in Umuahia. The finding of this study is consistent with Khuida and Siti (2004) study on the relationship between organizational career management and individual performance. The result of their study shows that there was significant and positive relationship between organization career management and the individual performance. Secondly, hypothesis two results show that there is a significant relationship between career counseling and effectiveness in selected banks in Umuahia. The finding of the present study is consistent with lyria, Namusonge and Karanja (2014) study on the effect of career management to the organizational performance in companies listed in Nairobi Security Exchange in Kenya. The findings of their study revealed that career management as a component of talent management had a positive and significant influence on the organizational performance. Thirdly, hypothesis three results revealed that, there is a significant relationship between career development and efficiency in selected banks in Umuahia. This is consistent with the finding of Rebeccah (2011) on the examination of the factors affecting career 
management among non-academic staff in public universities in Kenya: A case study of Jomo Kenyatta University of agriculture and technology. The study established that career planning, training and development and institutional framework had a positive effect on career management in JKUAT. Fourthly, hypothesis four results indicate that there is a significant relationship between career development and effectiveness in selected banks in Umuahia. This is in agreement with Ngirande and Musara (2014) finding on career management practices: impact of work design on employee retention. Their study found a strong correlations between job enrichment, job design and job enlargement.

\section{Conclusion}

Based on the findings above, the study concluded that; employee career management promotes organisational performance of banks. This means that career counseling improves the effectiveness and efficiency of banking businesses. Secondly, career development enhances the effectiveness and efficiency of banks.

\section{Recommendations}

Based on the conclusion of the study, the following recommendations were made. Zonal bank managers should advice the bank operating headquarters to include career counseling in the organisational strategic plan. Secondly, financial institutions should encourage their employees by developing their career through training, seminars, conferences and educational advancement to update their knowledge in other to be competitive in the banking industry.

\section{References}

Adebayo, O. S, Ayeni, G. O., \& Oyewole, F. A. (2013). Relationship between corporate governance and organizational performance: Nigerian listed organizations experience. International Journal of Business and Management Invention, 2(9), 1-6.

Agarwala, T. (2007). Strategic Human Resource Management Faculty of management studies, University of Delhi, Oxford University Press.

Agba, A. M. O., Festus, N., \& Ushie, E. M. (2010). Career development and employee commitment in industrial organisations in Calabar, Nigeria. American Journal of Scientific and Industrial Research, 1(2), 105-114.

Aplin, J. C., \& Gerster, D. K. (1978). Career development: and integration of individual and organizational needs. Persona Journal, 55, 23-29.

Armstrong, M. (2006). A handbook of human resource management practice, $10^{\text {eth }}$ Edition. Kogan Page. London and Philadelphia.

Arnold, J. (1996). The psychological contract: A concept in need of closer scrutiny? European Journal of Work and Organizational Psychology, 5(4), 511-20.

Azara, S., Syed, M. H. N., \& Muhammad, A. K. (2013).Employees training and organizational performance: Mediation by employees performance. Interdisciplinary Journal 
of Contemporary Research in Business, 5(4).

Cameron, K. S. (1986). Effectiveness as paradox: consensus and conflict in conceptions of organizational effectiveness. Management Science 32(5), 539-553.

Carmeli \& Tishler, A. (2004). The relationships between intangible organizational elements and organizational performance. Strategic Management Journal, 25, 1257-1278.

Cascio, W. F. (2007). Managing human resources: Productivity, quality of work life, profits. New Delhi: McGraw Hill.

Chenhall, R. H., \& Langfield-Smith, K. (2007). Multiple perspectives of performance measures' European Management Journal, 25, 266-282.

Daft, R. L. (2000). Organization theory and design (7th ed.). Cincinatti: South-Western Thomson.

Dessler, G., \& Verkkay, B. (2009). Human resource management. Delhi: Prentice Hall.

Dessler, G. (2013). Human Resource Management, Thirteenth Edition, Pearson.

Duca, I. (2013). Efficiency, Effectiveness and Profitability - Concepts Used in Assessing Public Expenditures in Education. Journal of Knowledge Management, Economics and Information Technology. Special Issue.

Dwight, M. (2012). The importance of organizational effectiveness. Available at: http://effectivemanagers.com/dwight-mihalicz/the-importance-of-organizational-effectivenes.

Farrell, D., \& Grant, A. J. (2005). China's looming talent shortage. The McKinsey Quarterly.

Grabara, J. (2006). Budowanie strategii przedsiębiorstwa z wykorzystaniem elastycznych systemów informacyjnych, PTI, Katowice.

Greenhaus, J., Callanan, G.A.,\& Godshalk, V.M., (2010). Career Management, Sage Publications, CA.

Hameed, A., \& Waheed, A. (2011).Employee development and its affect on employee performance: A conceptual framework. International Journal of Business and Social Science, 2(13).

Kagwiria, R. I., Namusonge, G. S., \& Karanja, K. (2014). Effect of career management to the organizational performance in companies listed in Nairobi Security Exchange in Kenya. International Journal of Science and Research (IJSR), 3(7).

Kaplan, R. S., Norton, D. P. (1993). Putting the Balanced Scorecard to Work, Harvard Business Review, September-October, pp. 134-147.

Katou, A. A. (2008). Measuring the impact of HRM on organisational performance, Journal of Industrial Engineering Management, 1(02), 119-142. 
Kehinde, J. S., Jegede, C. A., \& Akinlabi, H. B. (2012). Impact of leadership skill and strategies on banking sector performance: A Survey of Selected Consolidated Banks in Nigeria. The Business and Management Review, 3(1), 313-319.

Khuida, K. Y., \& Siti, Z. O. (2004). Relationship between organizational career management and individual performance. International Journal of Management Science, 11(2), 73-90.

Khulida, K. Y., \& Fee-Yean, T. (2015). Enhancing career commitment: The influence of human resource management practices. International Journal of Business and Society, 16(2), $237-246$.

Kong, H., Cheung, C., \& Zhang, H. Q. (2010). Career management systems: What are China's state-owned hotels practicing? International Journal of Contemporary Hospitality Management, 22(4), 467-482.

Koontz, H., \& Donnell, C. (1993). Introduction to Management. New York: Mcgraw- Hill Inc Kraimer, M. L., Seibert, S. E., Wayne, S. J., \& Liden, R. C. (2003). Examining employee performance and turnover intentions from a career perspective', Paper presented at the Annual meeting of the Academy of Management, Seattle.

Kumar, R. (2005). Research methodology: Step-by-step guide for beginners (2nd ed.). London: Sage.

Lambe, I. (2014). Corporate governance and organizational performance in the Nigerian Banking Industry. European Journal of Business and Management, 6(25).

Lebans, M., \& Euske, K. (2006). A conceptual and operational delineation of performance, Business Performance Measurement, Cambridge University Press.

Mabwe, N. (2015). Enhancing performance and competitive advantage through best career management practices in retail supermarket industry: A case of pick and pay retail supermarket, Masvingo. International Journal of Applied Research, 1(13), 386-394

Maina, R. A. (2011). Factors affecting career management among non-academic staff in public universities in Kenya: A case study of Jomo Kenyatta university of agriculture and technology. Master of Science Degree Thesis, Jomo Kenyatta University of Agriculture and Technology, Kenya.

Mkoji, D., \& Sikalieh, D. (2012). The influence of personality dimensions on organizational performance. International Journal of Humanities and Social Science, 2(17).

Moses, B. (1995). The manager's career coaching guide. Toronto, ON: BBM Human Resource Consultants.

Nada, I. J., \& Ibrahim, Z. (2014). The role of core competencies on organizational performance: an empirical study in the Iraqi private banking sector. European Scientific Journal, special edition, 1, 130-139. 
Ngirande, H., \& Musara, M. (2014). Career management practices: Impact of work design on employee retention. Mediterranean Journal of Social Sciences, 5(4).

Noe, R. A. (1996). Is career management related to employee development and performance? Journal of Organizational Behavior, 17(2), 119-123.

Okwiet, B. (2014). Career path and career management in the gardening company from SME sector. Polish Journal of Management Studies, 10(1).

Ombay, J. A., Otuya, W., \& Shiamwama, S. M. (2013).The Relationship between Career Counseling and Employee Productivity in Sugar Firms in Kakamega County, Kenya. International Journal of Business, Humanities and Technology, 3(7).

Osibanjo, A. O., Oyewunmi, A. E., \& Ojo, S. I. (2014). Career development as a determinant of organizational growth: Modelling the relationship between these constructs in the Nigerian banking industry. American International Journal of Social Science, 3(7).

Peace, I., \& Mohammed, A. M. (2014). Effect of employee commitment on organizational performance in Coca Cola Nigeria Limited Maiduguri, Borno State. IOSR Journal of Humanities and Social Science, 19(3), 33-41.

Sean, C. (2013). Career development is key to increasing employee engagement. Retrieved $5 / 5 / 16$ from http://www.halogensoftware.com/blog/career-development-is-key-to-increasing-employee-en gagement.

Sidiropoulou-Dimakakou, D., Argyropoulou, K., Drosos, N., Kaliris, A., \& Mikedaki, K. (2015). Exploring career management skills in higher education: perceived self-efficacy in career, career adaptability and career resilience in Greek university students. International Journal of Learning, Teaching and Educational Research, 14(2), 36-52.

Simonsen, P. (1997). Promoting a development culture in your organization: Using career development as a change agent. Palo Alto, CA: Davies-Black.

Sofijanova, E., \& Zabijakin-Chatleska, V. (2013). Employee involvement and organizational performance: evidence from the manufacturing sector in republic of Macedonia. Trakia Journal of Sciences, 11(1), 31-36.

Van Dam, K. (2004). Antecedents and consequences of employability orientation, European Journal of Work and Organizational Psychology, 13(1), 29-52.

Wong, S. C., \& Quek, L. S. (2015). Factors affecting individual career management among undergraduates in higher education institutions. International Journal of Academic Research in Business and Social Sciences, 5(10).

Zakari, M., Poku, K., \& Owusu-Ansah, W. (2013). Organizational culture and organisational performance: Empirical evidence from the banking industry in Ghana. International Journal of Business, Humanities and Technology, 3(1). 


\section{Copyright Disclaimer}

Copyright for this article is retained by the author(s), with first publication rights granted to the journal.

This is an open-access article distributed under the terms and conditions of the Creative Commons Attribution license (http://creativecommons.org/licenses/by/3.0/). 